\title{
Identity as Epistemology
}

\author{
M. A. Muqtedar Khan
}

\section{Purposeful Philosophy}

The first order of things requires an explication of the purpose of this inquiry into Islamic epistemology. In order to do so, I shall have to distinguish between academic philosophy, pure philosophy, and purposeful philosophy. Academic philosophy is a product of the modern academic institutional structure of recognition and discipline. This academic structure compels scholars to produce scholarship for the sake of scholarship. The principle of "publish or perish" is a guarantor of mediocrity. Such professional philosophical projects are often intellectually parasitic and may offer little or no new insights. For example, a visit to any library will reveal hundreds of books that deal with academic projects such as The Idea of Justice in Rawls Theory of Justice or the The Nature of Judgment in Kant's Critic of Judgment. Such projects contribute little to advance the understanding of justice or judgment and have no bearing on the normative nature of the society.

Pure philosophy is a lifestyle. The pure philosopher is a habitual speculator who relishes the sheer indulgence of the mind. It is not the product of reflection but the pleasures of reflection in themselves which sustain the pure philosopher. As one philosopher commented, "We could go to the mosque, pray, and come back to continue with our discussion of the question whether there is a God." The fact that the philosopher has just prayed does not settle the issue that as far as that philosopher is concerned there is a God and to question that is meaningless. Either the prayer was specious or the debate was meaningless. I suggest this because there is a disconnect between thought and action. The lifestyle of the pure philosopher, while immensely satisfactory to the philosopher concerned, trivializes both action

$\overline{\text { M.A. Muqtedar Khan is a visiting faculty in International Relations at Washington College, }}$ Maryland. 
and thought by delinking them. Philosophical activity must necessarily be constitutive. That is, it must have necessary implications for the identity, the actions, and the very life of the philosopher.

Purposeful philosophy is essentially an exercise in the search of Truth/truths, which does not delink the reality of the mind from the reality of social existence and seeks correspondence between ideas and action. For a purposeful philosopher, ideas must have consequences in terms of agent identity and agent action, that is, ideas must play a constitutive not instrumental role in the philosopher's existence and this must be manifest in the externality of the agent. It is not my concern, at this moment, whether this purpose in the philosopher's existence is prior to or as product of his/her philosophical activity. It is enough that there be a purpose. Purpose may be a driving force, it may be a sought after goal, but it must be an essential element of philosophical activity. I place the philosophical activity of a Muslim in this category. It is here that philosophy begins to gain an identity, and we can begin to talk meaningfully of an Islamic philosophy.

The project to revive Islamic philosophical thinking has one broad and one specific purpose. It is my understanding that until the Muslim community (Ummah) produces its own philosophers who reflect on the present and share this understanding with their fellow Muslims, not only our lands and our resources, but also our cultures, our minds, our ideas, and all our moral and material endeavors will remain colonized by others. The slavephilosopher can only resent or imitate the master, for along with his body and mind, his creativity is also enslaved. Our task is to free the imagination of the slave from the shadow of the master's ideas and also from the limits that contemporary conditions put on the conceptions of the slave-self. We must avoid the trap of seeking the self in the self of the master; ${ }^{1}$ we must also avoid seeking the self of the master in our self. ${ }^{2}$ We must discover our self as if the master did not exist. To be able to think as if there was no master, to begin thought from a state of freedom is the general purpose of the project to revive Islamic philosophy.

The revival of Islamic philosophical thinking is necessary for the purpose of critically reviewing Muslim understanding of Islam and its continued relevance to the evolving order of human existence. ${ }^{3}$ In the absence of critical thinking, dogmatism and stagnant orthodoxies threaten the vitality of Islamic civilization. In the absence of critical thinkers, the task of relating principles to reality and texts to context is usurped by those whose responsibilities should be confined to the explanation of principles and the 
motivation of society to adhere to these principles. We live in an era where the important task of self-criticism has been delegated to the dominant other - the West. The Western critique of Muslim societies serves the sole purpose of universalizing eurocentrism and underscoring the claim that Western values are superior and that the Western present is the future of all other cultures and civilizations. It is with these noble purposes in mind that we embark on the search for an Islamic epistemology. We believe that Islamic epistemology will enable us to provide the foundations for a liberatory philosophy that will bring the Muslim out of the darkness of slavery (jahiliyyah) and into the light (Islam) of hikmah (wisdom).

Epistemology is an intellectual enterprise that seeks to answer two fundamental questions. It identifies what constitutes knowledge and seeks to develop methodologies for acquiring knowledge. Epistemology is the only self-constituting inquiry. All other inquiries rely on epistemology for definition as well as legitimacy. This does not mean that there are no knowledge claims that are prior to epistemology. Indeed, philosophical enterprises start with arbitrary but intuitive axiomatic assumptions and then adjust these working assumptions after completing their epistemological inquiries. The most important assumption and conclusion of an epistemological enterprise is with regards to the criterion for segregation of truth from falsehood and reality from appearance. What determines truth - reason, senses, miracles, or revelation? That is the central issue from which all else derives. ${ }^{4}$

The contemporary revival of Islam has manifested itself in various forms, from architecture to politics. In the intellectual arena the revival of Islam is taking a specific form. It is seeking to discover a uniquely Islamic form of epistemology and knowledge. ${ }^{5} \mathrm{I}$ think in doing so it implicates knowledge, values, identity, and epistemology. While this is, from a civilizational perspective, a positive development, it also raises serious philosophical issues. The search for Islamic knowledges, be they science, philosophy, epistemology, or social sciences, seems to suggest that values are prior to knowledge and that identity implicates epistemology.

Consider for example the Islamization of Knowledge project. It is a consequence of certain a priori assumptions about Muslims, Islam, and Western social sciences. Without delving into the details of the project itself, I would like to point out that Islamization of Knowledge presupposes that Islam and Knowledge can be divorced. The project actually envisages an Islam without knowledge and knowledge without Islam. In a 
bizarre intellectual twist, jahilliyyah and Islam are aligned. For someone for whom knowledge, enlightenment, and Islam are synonymous this distinction between Islam and knowledge is problematic. If one were to explore further the implications of the philosophical assumptions of Islamization of Knowledge, one would realize that it allows us to imagine knowledge without values. In a strange fashion, values precede knowledge rather than being the outcome of knowledge. This delinking of knowledge and values implies that the ignorant can be good while those who know can be bad.

Clearly, this contradicts the Quranic understanding of the knower being better than those who do not know (39:9). In order to resolve this problem we have to redefine what it means "to know." Thus when we posit two kinds of knowledges, that which is informed by Islamic values and that which is devoid of Islamic values, we are making a confused statement about the relationship between values and knowledge. If Western social science is un-Islamic, devoid of Islamic values, then it is either "objective," that is, value free, or else it is based on a set of values which are un-Islamic. In the former case, by Islamizing knowledge we are corrupting pure knowledge with ideology (our current understanding of Islam). If on the other hand we believe that Western social science is based on un-Islamic values then why are we seeking to Islamize a product of un-Islamic origin?

Let's take another look at this philosophical dilemma. The claim that there is such thing as Islamic philosophy has been made very eloquently by Dr. Seyyed Hossein Nasr. In his lecture, Dr. Nasr made a distinction between Islamic philosophy and the philosophical work of Muslims such as Iqbal and Rumi who, in his opinion, were not Islamic philosophers. ${ }^{6}$ This position once again places identity prior to epistemology and methodology. Self is prior to philosophy - it is not a product of philosophy. For to claim an Islamic philosophy is to assert the existence of an Islamic self which philosophizes without implicating the self; that is, self and philosophy are forever sundered. Now we are forced to conceptualize self-reflection and reflection as two mutually exclusive processes. If the self is not a product of philosophical reflection, then what is self-reflection? We are forced to imagine a metaphilosophy of the self, prior to Islamic philosophy. This dilemma is easily resolved if we accept the message of the Qur'an as the metaphilosophy of the self that is prior to Islamic philosophy. While Islamic philosophers have understood the Qur'an as a source of truth, they have not seen the Holy Qur'an as I describe it - the metaphilosophy of the self. 
This relationship between identity and knowledge is significant as well as problematic. It is one of the areas that contemporary Islamic philosophers must explore, specially at a time when Islamic claims to truth are not presented in universal terms by Muslims themselves. Secondly, the relationship between values and knowledge or Islam and knowledge also needs clarification. Until these issues are settled in a meaningful sense, efforts toward advancing knowledge based on claims of Islamic particularities, whether at the level of epistemology or at the level of applied sciences, will remain problematic. ${ }^{7}$

\section{Knowledge by Presence}

Mehdi Yazdi's book, The Principles of Epistemology in Islamic Philosophy: Knowledge by Presence, is an important work and in many ways a significant milestone in the contemporary history of Islamic philosophical thought. ${ }^{8}$ It has been a long time since any Islamic philosopher has taken up a project of this magnitude. The fact that it has been written originally in English is itself a statement. Besides, the search for principles of epistemology that will identify the means to develop a knowledge that is Islamic is one of the major impulses of the current Islamic revivalist ethos. Any serious claim to the identification of this sacred path deserves serious attention. It was, therefore, with great hope and anticipation that I approached this book. Encounters between readers and books are rarely value free. One cannot but entertain a priori expectations, and it is with regards to these expectations that the merit of a book is often gauged. Let me first identify the expectations with which I approached this book. I was looking for the secret/sacred/straight path that would lead me to the mythical wealth of "Islamic wisdom," to the "Truth" from which our minds and our societies have been so tragically exiled. I thought that perhaps in this book I would find "the way," or at least a way.

In this book, Yazdi seeks to achieve two goals. He is trying to elucidate the meaning of knowledge by presence, 'ilm al-hudürī, and is seeking to demonstrate that mysticism is a type of knowledge by presence. In a subtle fashion, the book also partakes in a dispute with Western philosophy over what constitutes "knowledge." The author argues that Western philosophy, given its rationalist tendency, has consistently excluded certain types of knowledges, such as irfan - mystical apprehension — and other mystical experiences from the realm of philosophical knowledge. By establishing that mystical experience is an instance of knowledge by presence, the 
author hopes to include mystical experiences and mystical understanding of things (both eternal and temporal) as legitimate knowledge. In this endeavor, the author is clearly writing for the benefit of Western rational philosophers, whom he hopes to persuade that Islamic mysticism is actually an important aspect of Islamic philosophy and deserving of being recognized as such. Dr. Nasr, in his book on the life and works of Sadr al-Din Shirazi, describes a similar intellectual approach as "transcendent theosophy." 9 The term is more appropriate than "philosophy" as understood in the Western tradition or falsafah as understood in the Islamic tradition.

The book is more about a specific kind of knowledge, knowledge by presence, than epistemology or Islamic epistemology. The idea of knowledge by presence is at once strikingly simple and deeply profound. Knowledge by presence, as Yazdi describes it, is the knowledge of the self obtained without the mediation of any linguistic or mental representation (p. 2). There are two outstanding aspects of knowledge by presence. The first entails the resolution of the Cartesian divide between subject and object, and the second concerns its freedom from the truth-falsehood dichotomy. In all forms of knowledges there are two important elements the knower and the known - but in knowledge of the self the knower and the known, or the object and the subject, are unified. Thus knowledge by presence is knowledge of the self by the self.

This is not exactly a unique philosophical position. Western philosophers like Charles Taylor and social theorists like Herbert Mead and Anthony Giddens have extensively explored the constitution, understanding, and representation of the self. Indeed, they all recognize humans as those special beings who are "reflexive," that is, they possess the capacity to indicate to the self, know the self, and even act upon the self. Thus in equating the knower and the known, knowledge by presence is not alone. But knowledge by presence is unique in one sense: It claims to be a knowledge that is not mediated by either mental or linguistic representations. In other words, knowledge by presence is a consciousness or self-awareness, which is prior to language and knowledge. It is some form of primordial, even primal, awareness of the self.

The author seeks to illustrate this cognitive phenomenon by discussing the sensation of pain. The sophisticated arguments advanced by the author not withstanding, knowledge by presence is in its most fundamental instance a sensation of the self, such as pain, ecstasy, happiness. But beyond this, when the knowledge of the self goes beyond sensation to intel- 
lectual apprehension, then the author would have difficulty in arguing that there can be a knowledge of the self which is not a sensation and is also not mediated by linguistic or mental images. Through his focus on pain, Yazdi seems to convey that knowledge by presence is like the knowledge an animal would have about itself.

Moreover, the book does not advance any discussion about the value of such knowledge. So we feel pain. So what? The author eschews any discussion of "meaning." Things, experiences, ideas, thoughts, and objects gain meaning only through representation - through cultural relevance, linguistic significance, or rational analysis. Meanings lie in correspondence, in representations. The self as an object of self-inquiry can have no meaning unless we are able to indicate to ourselves what this "self" means. Indeed, I shall venture to assert that there is no "self" until meanings have been associated with the self. When the author claims that knowledge by self is beyond the true-false dichotomy, he is suggesting that perhaps it is also meaningless.

Ibrahim Kalin, during the discussion on this topic at the symposium, ${ }^{10}$ pointed out that facts (such as pain) can be real or unreal but only statements can be true or false. While this may seem a reasonable defense of knowledge by presence, I think it too is problematic. Are ideas real? Can ideas be true or false? The attempt to take knowledge by presence out of the realm of truth and falsehood also takes it out of the realm of epistemology and places it in the realm of ontology where the only germane issue is the reality of sensation. Rather than discussing the nature of our knowledge about the sensation of pain we would be discussing the being of pain. But this gambit makes sensation an object or a thing. Things by themselves are not knowledge; knowing subjects possess knowledge about things. Therefore, if pain itself assumes the form of an object, then the subjectobject condition that knowledge by presence was seeking to eschew is reproduced. Thus pain itself has become the object that the subject seeks to know or claims to know, and the object-subject duality is reproduced. This example also raises the question whether knowledge by presence is equating sensation to knowing.

This problematique in the scope of knowledge by presence becomes apparent when the author discusses mysticism. If the mystical experience is knowledge by presence then any discussion of the experience itself becomes knowledge by correspondence. In the narration of the mystical experience one has no choice but to use representation to communicate the 
experience even to the self. Thus any attempt to make sense of the mystical sensation becomes knowledge by correspondence. The author makes many contradictory claims about mystical experience. For example, he claims that mystical consciousness is nonrepresentational and then immediately asserts that mysticism is empirical and scientific (pp. 104-105). If mysticism is an empirical and scientific knowledge then it should be verifiable. Moreover, if the mystical consciousness itself is nonrepresentational, then how can the author claim that mysticism is scientific?

The author is clearly moving from philosophy to politics. He is trying hard to legitimize mysticism as a philosophy and a science on a par with Western philosophy, and the entire detour into knowledge by presence is a stepping stone toward this goal. The book raises more questions than it answers. What is the purpose of this book, which claims to advance principles of epistemology in Islam? The book is addressing Western philosophy with the purpose of gaining acceptance for mystical experience as a philosophical knowledge. There is very little in this book that concerns Islam or Muslims. The book has little to say about the condition of knowledge, epistemology, or philosophy in Islam or the present Muslim world. Indeed, the book is written as if Islamic values and teaching, the Qur'an, and Islamic traditions are nonexistent. Except for occasional references to some Muslim philosophers like Ibn Sina (the author prefers the Western version Avicenna) and a more serious connection with Suhrawardi, there is very little to justify its claim to identify with the Islamic philosophical tradition.

Even the discussions of mysticism are not directly based on Islamic mysticism. The author prefers to speak of it in more general terms. Sadly, one is compelled to reach a harsh conclusion that this book is not about Islamic epistemology; it is more like an intellectual justification by mysticism for inclusion under the label philosophy. Dr. Nasr, who has written a glowing introduction to this book, describes the author as "an Islamic philosopher belonging to the living tradition of Islamic Philosophy" (p. xi). This brings us back once again to the relationship between identity and epistemology. What do we mean by an Islamic philosophy and Islamic philosopher?

Dr. Nasr is the most prominent proponent of the claim that there is such a thing as Islamic philosophy and that it is not only distinct from ancient Greek philosophies and modern Westem philosophies, but it is also distinct from the philosophical output of Muslim intellectuals. To exclude the philosophical work of Muslims, even prominent ones like Jalaluddin Rumi and Allahma Iqbal, from the genre of Islamic philosophy is in my opinion 
a really serious claim. ${ }^{11}$ I wish to scrutinize Yazdi's book with reference to this claim. Dr. Nasr writes:

Islamic philosophy, like everything else Islamic, is deeply rooted in the Quran and Hadith. Islamic philosophy is Islamic not only by virtue of the fact that it was cultivated in the Islamic World and by Muslims but because it derives its principles, inspiration and many of the questions with which it has been concerned from the sources of Islamic revelation. ${ }^{12}$

Besides the fact that Islamic philosophy developed within a Qur'anic universe, Dr. Nasr identifies three other criteria that makes Islamic philosophy Islamic philosophy. Islamic philosophy is fundamentally dependent on revelation and often described as prophetic philosophy, it employs 'aql - a combination of reason and intellect - which is Islamic in its nature, and finally, the proponents of this science of sciences are believing Muslims who live by the divine law. ${ }^{13}$

I agree with Dr. Nasr that indeed once the Islamic self is constituted by Qur'anic revelation, the philosophical output of this self would be Islamic. But Yazdi's book does not reflect the Islamic characteristics that Dr. Nasr describes. The book is not addressing any of the concerns of the Qur'an or Hadith. I am sure that the Qur'an and Hadith are not interested in proving to the West that mysticism is a form of philosophy. It does not employ the Qur'an or Hadith to mediate or substantiate any claims. It does not even seek to assert that there is such a thing as Islamic philosophy. Indeed, I suspect that the use of the term Islamic philosophy in the title is a marketing gimmick. Certainly the substance of the book does not correspond to what the title suggests.

Finally, I must conclude that while Yazdi succeeds in describing the idea of knowledge by presence, he has failed to explain its relevance to Islam or Islamic ways of understanding reality. If one makes all the necessary concessions and agrees with the author that knowledge by presence is knowledge of God or even a unification with God, then we are led to a startling conclusion - knowledge by presence makes revelation redundant. During the symposium, the advocates of knowledge by presence were appalled when I made this claim; therefore, I shall use this opportunity to carefully elaborate how in my opinion knowledge by presence, if accepted in its highest form, can make revelation redundant.

Knowledge by presence, as Yazdi has so painstakingly described, is unmediated and unrepresented knowledge, "devoid of linguistic and men- 
tal representations" (p. 2). If one can have knowledge of God through knowledge by presence it means that the self and God are one, since knowledge by presence is only unmediated knowledge of the self. Thus if one can know God without God representing himself to us, then why do we need revelation? The Qur'an is representation. It is a linguistic representation/ intervention by the divine. It is God's representation of human and divine realities to humanity, inasmuch as the Islamic universe is the Qur'anic universe it is represented. To claim access to knowledge of anything other then the immediate and primal self through knowledge by presence is to assert that revelation is not necessary. I personally think the author is making too much out of a human instinct for self-awareness. Other Muslim thinkers like Ibn Tufayl ${ }^{14}$ have tried to argue that one can know Truth without revelation, but through reason. This is the first instance where both reason and revelation are marginalized as instruments of knowing. The only claim that I find acceptable about knowledge by presence is that human agents have an instinct for self-awareness. And since the self is impossible without the prior existence of God, one can by virtue of reason claim that self-awareness is in a profound instance, awareness of God, but only after reason has finessed instinct.

Despite its obvious merit as a philosophical treatise, Mahdi Yazdi's book unfortunately has little to offer to the present Muslim world that is seeking to transcend its current conditions. It has little to offer to Muslim intellectuals struggling to come to terms with the consequences of modernity and postmodemity. It also has little to offer Muslim intellectuals who are seeking to revitalize Islam in contemporary Muslim societies. It belongs to the class of academic philosophy, excellent in its category, but it does not contribute much by way of epistemological tools for the contemporary struggle to revive Islamic civilization. Yes, a high-quality book like this does indicate the intellectual resurgence of Muslims and the revival of Islamic thought. But it is more a manifestation of, rather than a contributor to, this revival. I am aware that it is not fair to be critical of the book that does not claim anything more than what it actually delivers. Nevertheless, it was the quest for an Islamic epistemology that generated my interest in this book. On that score it did not meet my expectations. The title - Principles of Islamic Epistemology - in a way is misleading and makes false promises and may well be solely responsible for my disappointment. Perhaps, Knowledge by Presence as Philosophy or Mystical Experience as Philosophy would be more appropriate but less marketable titles. 


\section{Identity as Epistemology?}

Islamic epistemology is an interesting, even inspiring idea. But this idea could make Muslim intellectuals parochial and lead to a "ghettoization" of the concept of knowledge. There are many kinds of knowledge and many epistemologies. Even within the Islamic universe there are many kinds of epistemologies. Some of Islam's greatest thinkers themselves are representative of the wide array of approaches that Muslims have taken toward knowledge. Ibn Haytham's empiricism, Ibn Khaldun's historical rationalism, Ibn Rushd's rationalism, Ibn Arabi's vision, Mulla Sadra's intellection - all are testimonials to the epistemological plurality of the Islamic approach to knowledge. ${ }^{15}$ Therefore, this quest for an essentialist Islamic theory of knowledge may have an ideological appeal, but unfortunately it has stunted the development of contemporary Islamic thought by taking many of its best thinkers on a wild goose chase. Either we have the temerity and misfortune to label many of our great thinkers as un-Islamic in their methodology and in their conception of knowledge and privilege only a few, or we must otherwise recognize that there are many Islamic epistemologies.

I believe that there are basically two varieties of knowledge - those that vary according to the "objects" of cognition and those that vary according to the "subjects" of cognition. Different epistemologies serve different subjects and apprehend different kinds of objects. For instance, interpretive epistemologies apprehend meanings, positivist epistemologies deduce regularities, constructivist epistemologies explore the dialectics between matter and mind. While there are many dogmatic philosophers of science who maintain the validity of only singular epistemologies, one can take comfort in the thought that they are adequately recompensed for their philosophical intransigence by being limited to a partial understanding of the world. Epistemological singularity is like color blindness - it makes you miss other dimensions of reality. The many facets of reality can only be accessed through a systematic synthesis of multiple epistemologies.

There are, broadly speaking, three types of objects: divine, intellectual/ideational, and material or God, mind, and matter. Each of these three essential commodities ${ }^{16}$ is partially or even fully knowable to the human subject. The human subject can know God, who is clearly on a higher ontological level. It can know the intellect whose ontological station is both identical as well as simultaneous and concurrent with its own existence. And it can know matter which lies below its ontological station. 
Clearly, the knowledge that one develops about these different objects of knowledge are related, even interdependent, but certainly not identical. Can the way one studies the attributes of sulphur, such as its melting point, be similar to the way we explore the attributes of the mind, such as ideas or identity? And can this way also allow us to understand the attributes of God, such as eternity and self-subsistence? Certainly not. Many enthusiastic Muslim intellectuals may fill tomes claiming that there is a unique Islamic methodology which will endow us with this miraculous power. But they have yet to demonstrate it in action. Clearly, there are different epistemologies with different capabilities which allow us to know various objects; God through revelation, worship, contemplation, through textual and natural signs; ideas through interpretation and matter through positive sciences.

The assumption that there is an Islamic epistemology presupposes that there is an Islamic subjectivity. This is an epistemological claim that beliefs shape what we know. It takes one down a slippery slope where the distinction between what is "belief" and what is "known" becomes unclear. In other words the distinction between the application of epistemology and the definition of epistemology begins to disappear. Beliefs, even rational beliefs, are by nature prior to knowledge and cannot constitute knowledge itself; however, they are essential ingredients of identity. Identity now becomes prior to epistemology and even determines epistemology by tailoring it in order to justify or prove the beliefs on which it is premised. Thus identity essentially sabotages the validity of epistemology by employing it in self-defense rather than in deploying it to apprehend objects other than itself. This relationship between identity and epistemology presents ideology as knowledge. ${ }^{17}$ Such knowledge systems are in a sense spurious and will never deliver viable knowledge that can empower human agency and transform the human condition for better in both material and spiritual sense.

Even though Islamic identity constitutes a type of subjectivity, I am not referring to socially constructed subjectivities as sources of epistemology. I believe there are two basic forms of human subjectivities - "mystical man" and the "material man." Mystical man seeks to submit entirely to the will of God. This agent is contemplative and seeks to only annihilate the self in search of a union with the Eternal One. Mystical man needs to know only the elements of the path that will lead him to self-annihilation and divine union. The epistemological needs of mystical man, whose existence 
is confined to the spiritual and ideational realms only, are geared toward a search for the unseen; for extracting the divine from the mundane, the eternal from the temporal, and the ego from the self. Mystical technologies of irfan, guidance from masters, and visions of truth are his major tools. Mystical man needs the ability to provide profound analysis of the revealed texts in search for hidden meanings. While a more detailed discussion of mystical epistemologies may be reserved for another day, it will suffice to say that this agency needs only interpretive and constructivist methods of knowledge acquisition.

Material man, in contrast to mystical man, seeks to dominate the dunya (material world). Material man celebrates the self and seeks to impose its dominion on others - nature, space, and time. His epistemological needs are toward physical empowerment for control of the body, for health, for longevity, for mastering nature, for unlimited all-around conquest. This kind of human agent is not in search of meanings, it imposes meanings. Material man needs epistemologies of domination and, therefore, seeks positivist sciences that allow control.

Clearly, Islamic subjectivity is not confined to one of the archetypes described above. It includes both. As God's vicegerent on earth (2:30), the human agent is both 'abd Allah (slave of Allah) and khalifa (deputy). $\mathrm{He}$ submits to Allah but dominates and rules over the rest of the creation as God's deputy. Unfortunately, the religious sciences tend to produce only mystical man in search of submission and the secular sciences produce only material man in pursuit of power. The increasingly mystical inclination of the Muslim agent and his surrender of the material world to the secular scientific Western agent is a tragic offshoot of this division of knowledge. It seems that while the Muslim agent is becoming increasingly mystical, relinquishing the material world (in his sciences), modem man is become increasingly material and banishing the mystical world, by making the same error in understanding the scope of knowledge and epistemology. To realize the true deputy of God, we have to unite these two sciences, not by searching for a mythical epistemology that is all-encompassing, but by adopting a pluralistic approach to epistemology. Until then we will continue to mistake identity and its discursive defence as epistemology and knowledge.

\section{Notes}

1. For example, tracing the Islamic roots of modern sciences and modernity.

2. For example, seeking democracy in Islamic traditions. 
3. See M.A. Muqtedar Khan, "The Need to Revive Islamic Philosophy," Intellectual Discourse 6, no. 1 (1998): 1-9.

4. See Arthur C. Danto, What Philosophy Is: A Guide to the Elements (New York: Harper \& Row, 1968); D.Z. Phillips, Introducing Philosophy (Cambridge, MA: Blackwell, 1996); Bertrand Russell, The Problems of Philosophy (London: Oxford University Press, 1975).

5. For a comprehensive review, see Leif Stenberg, The Islamization of Science: Four Muslim Positions Developing an Islamic Modernity (Lund: Lund University, 1996). For examples see AbdulHameed AbuSulayman, Islamization: Reforming Contemporary Knowledge (Herndon, VA: International Institute of Islamic Thought, 1994), and Louay Safi, The Foundation of Knowledge: A Contemporary Study in Islamic and Western Methods of Inquiry (Kuala Lumpur: IIUM \& IIIT, 1996).

6. Dr. Nasr made this remark during the course of his lecture on "What is Islamic Philosophy" at the School of Islamic Social Sciences at Leesburg, Virginia, February, 1999.

7. See M.A. Muqtedar Khan, "Self and Knowledge," American Journal of Islamic Social Sciences 16, no. 1 (Spring 1999): v-xi.

8. Mehdi Ha'iri Yazdi, The Principles of Epistemology in Islamic Philosophy: Knowledge by Presence (Albany: State University of New York Press, 1992).

9. Seyyed Hossein Nasr, Sadr al-Din Shirazi and His Transcendent Theosophy (Tehran: Institute for Humanities and Cultural Studies, 1978), 57.

10. The Symposium on Islamic Epistemology held on February 27, 1999, at IIIT, Herndon, Virginia.

11. Seyyed Hossein Nasr, "What is Islamic Philosophy?"

12. Seyyed Hossein Nasr, "The Quran and Hadith as Source and Inspiration of Islamic Philosophy," in Seyyed Hossein Nasr and Oliver Leaman (ed.), History of Islamic Philosophy, Part I (London: Routledge, 1996), 27.

13. Seyyed Hossein Nasr, "Introduction," History of Islamic Philosophy, 16.

14. For a review of Ibn Tufayl's ideas told through the story of Hayy Ibn Yaqzan, see Majid Fakhry, A History of Islamic Philosophy (New York: Columbia University Press, 1983).

15. For a quick review, see Majid Fakhry, A Short Introduction to Islamic Philosophy, Theology and Mysticism (Oxford: One World Publications, 1996). See chapter 4, "Islamic Spirituality and Thought," in Seyyed Hossein Nasr, A Young Muslim's Guide to the Modern World (Chicago: Kazi Publications, 1994); and Oliver Leaman, An Introduction to Medieval Islamic Philosophy (Cambridge: Cambridge University Press, 1985). For more detailed surveys, see M.M. Sharif (ed.), A History of Muslim Philosophy (Karachi: Royal Book Company, 1963); Seyyed Hossein Nasr and Oliver Leaman (ed.), History of Islamic Philosophy; and Majid Fakhry, A History of Islamic Philosophy (New York: Columbia University Press, 1983).

16. In the ultimate sense, there is only one reality, only one substance and one existence - God. The other realities, mind and matter are dependent on the former for existence.

17. I have explored this idea in considerable detail elsewhere. See M.A. Muqtedar Khan, "Self and Knowledge," v-xi. 